\title{
URBAN TOURISM AND CULTURAL TOURISM IN THE CONTEXT O BELIEF TOURISM: KONYA SAMPLE
}

\author{
Ibrahim Kaynak Kaynak ${ }^{1}$ \\ Tahsin Karabulut ${ }^{2}$
}

\begin{abstract}
The Anatolia is the ferment, cradle of civilizations and cultures, and a heaven on earth. The yeast of the civilization dough in this cradle has been put at the 10.000's B.C. and has reached up to modern times by a rich, sweet temper, which makes it a rich, generous geographical place and destination.

Too many cities in Anatolia are hosting this historical heritage. Konya, is one of the most rooted cities of our Homeland both culturally and industrially. The documents proving that the revolutionary acts of conversion from nomadism, forager into settlement and agricultural life, in the history of humanity, have realized in these lands, have occured during the Konya Çatalhöyük excavation works. Konya which is assumed as the cradle of world civilization today, has an important location in terms of faith history. The Mother Goddess which has formed in Çatalhöyük at 6500's B.C., also forms the first cores of paganist religions of the Kybele cult. Konya has also hosted other religions during the historical phase. In this study, by evaluating the belief and cultural values within Konya in terms of Christianity and Islam religions, its contribution onto the Urban Tourism will be discoursed.
\end{abstract}

Key Words: Anatholian Culture, Çatalhöyük, Urban Tourism, Christianity, Islam

\section{INTRODUCTION}

As a form of organisation, the city is the source of civilization. This urban civilization's yeast is formed of religion, geography, politics and economy equation. The society which forms out the city, is served by religion in terms of mentality, geography in terms of locations, politics in terms of administration and economy in terms of forming the economic relations. In the Anatolia, Mesopotamia, Egypt, Greek and Roma which are the cradle of the civilization, the religion with all its variations has always been a common source of value. In this formation, the religious structures have played a leading role in forming a civilization through their temples and altars, sanctuaries and sites; the politics with its urban administration, municipality and parliament structures; economy with its marketplaces and bazaars, have fulfilled their duty of forming the urban identity. The constituent element of the last civilization in Anatolia has been Islam.

Thesimilardevelopmentshave been encountered in the Islamic civilization and the cities have been the indispensable elements of the life. Konya, has been represented as the Islamic city until the modern times. The western cities which have obtained a GreekRoman and Christion line, has reformed a new urbanisation process through the Industrial revolution since the 18. century. This new urban civilization's main characteristic has started with the population migration from rural to urban and by forming a new manner of work and life, have led to a modern urbanisation. The religion and politics which have been a form of organisation in the processes of civilization, occured to be the elements

\footnotetext{
${ }^{1}$ Asst. Prof. Dr., Necmettin Erbakan University, Tourism Faculty, Turkey, e-mail: ihkaynak@konya.edu.tr.

${ }^{2}$ Assoc. Prof. Dr., Necmettin Erbakan University, Faculty of Social Sciences and Humanities, Turkey, e-mail: tkarabulut@konya.edu.tr.
} 
determining the society and social organisation, the economy on the other hand, through capitalism and modernisation phases, has been the main element determining the city, society and social organisation. By means of industrialisation and modernisation phases, an economy focused conception has occured in the cities. In this point of view, changing the nature of the city, the sanctuary focused urban structures have left their places to trade focused structures. From now on, the avenues of city aredirecting not tothereligiousstructures but totheshoppingcenters.

Wearecurrently on a world where anything is quickly produced and consumed, the information and transportation spreading and developing fast. This conception and manner, has become a life style which effects both young and old, from rich to poor as a form of living philosophy.

Within a consume based economical conception, the cities have started to get their own parts, the city and city cultures formed of centuries, have converted into a consume culture. On the other hand, the current time has dominated the past, the cultural and religious continuations have been broken. Thanks to tourism which is among the biggest economic sectors of the world, and a social, modern fact, the cities have been a means to form a historical consciousness by highlighting their historical continousness, thus, the studies have established in order to protect the historical identity of cities. As a result, the urban tourism has been started to mention as an alternative tourism possibility. In too many cities in Anatolia the studies oriented on the urban tourism have been paid attention by stepping the Historical Environment Protection Policies. In the studies, Konya has started to take its own part consequently, the tourists of the city at least had the opportunity to see Konya through its past and today. Within the context of Historical Environment Protection Policies, the cities with a civilization identity, have started to step in with their own cultural assets.

\section{CITY AND THE TOURISM}

The city is not only a geographical place which adjusts the humane relationships by obliging the mankind to mankind, but is also a life circle which covers the sociopsychological life. The city as a place of living, is one of the most important yet most complex spatial areas (Alver,2012:25).From this point of view, the city, expresses itself with a natural geographical area, through a landscape invaluable to be seen with its buildings, streets, roads, pavements, markets, amusement places, museums, religious, financial and political structures (Alver,2012:25). Tourism is on the other hand an activity of travel which consists of the holiday the "escape and directing", amusement, rest, culture and faith oriented people.

The tourism fact is a modern phenomenon. This fact belonging to contemporary modern societies, has converted into an organisation which anyone can participate in through the globalisation. This organisation, alongside with its formation of sociocultural action between the tourist sending and tourist receiving countries, has established an economic motion related with the countries. The tourism, thanks to its economical dimension, has directed the countries into alternative tourism searches, and the last stop it arrived has been the urban tourism. The urban tourism, is meeting more than half the demand for tourism all over the world.

Even though the world tourism's appearance goes up to the 19. century, the expectations of tourism into the urban economics have been a subject on the agenda of local administrations, after 1980 (Kizldere,2007:27).The urban tourism is a type of tourism 
which is carried out in big cities of metropol scale. The interest on the "Urban Tourism" which consists of holiday, obtaining historical and cultural information and experience, spectating sportive activities, participating in the artistic activities, familial and friend visits, shopping and work travels, is dramatically increasing all over the world (Emekli,2013:138).

All the cities come into prominence with its own features. Even one word, would be enough to give a thought on its identity. For example, even though there are too many historical and cultural heritages in Konya, the first place to come into mind is Mevlana. This is, its authentic and introductory feature. In that case, Mevlana steps in formation of Konya's urban identity, among all those works since long time. That looks enough by itself in formation of Konya's urban identity and image. The city has the capacity of an open-air museum with its mosques, Moslem theologic schools, hamams and foundation works of Seljukian and Ottoman eras. This open air museum appearance, has started with Konya/Çatalhöyük, by tracking the Roma, Byzantine, Seljuk and Ottomans.

The economical, political and socio-cultural conversions the social structures and individuals experience, have contributed positively and negatively on the city to have a new identity. Those conversions and structuring models formed through the globalisation, is carried out in Konya and our country under the urban renewal and urban construction conceptions just like it is all over the world. Through this phase we experience, the branding of the cities, and formation of brand cities have been on the agenda, to this end, for branding the cities in a planned manner, the Culture and Tourism Ministry has established "Turkey Tourism Strategy 2023 and Tourism Strategy Brand City Action plan" (2007-2013) in 2007. Within the context of this plan, by boosting the urban tourism on the cities like Istanbul, Ankara, Izmir and Antalya which are selected under the Brand Cities Project; and by boosting the cultural tourism in cities such as Adiyaman, Amasya, Bursa, Edirne, Gaziantep, Hatay; Konya, Kütahya, Manisa, Nevşehir, Kars, Mardin, Sivas, Şanliurfa and Trabzon, it is foreseen to form the brand cultural cities (www.şehirplanlam.org).

The historical center of Konya city, satisfies not only the urban central function where the economical activity and administrative services are focused on, which serves all the urban population in terms of easy accessibility/transportability and urban field usage design and functional positioning and its central location in terms of geography, but also thanks to its spatial and functional pattern accompanied by cultural heritage values and on the other hand, the values subject to its close vicinity's cultural heritage, has appeared to be an urban area with spatial and functional, cultural tourism oriented development potential(Özcan,2009:4).

\section{STUDIES ON THE URBAN TOURISM IN KONYA}

In tourism, the geographical, cultural and historical features the cities have are presented to visitors as the urban tourism activities within the natural life of that society. The cities are developing the protection and zoning projects for being able to make use of the tourism by bringing their authentic features to forefront.The changes experienced in the behavior and lifestyles of people, has caused an increase in the interest to the alternative tourism types in spite of the sea-sand-sun conception holidays. In this point, the urban tourism which contains of short term visits to cities related with the social, artistic and many other aims have stepped in (İçellioğlu,2014:41). 
At the base of this interest, is the desire to know and understand better, the physical, social, cultural and functional identities people have established.At this juncture, Konya, besides having all those identities, has been foreseen as a cultural city within the context of "Turkey Tourism Strategy 2023 and Tourism Strategy Brand City Action Plan" (20072013) of the Culture and Tourism Ministry in 2007.

The Konya historical city center concentrates basically on four focals.First of them is the hill town known as Alâeddin Tepesi, and its close vicinity.The second urban focal is Mevlana Museum and its close vicinity which forms the historical urban center.The third focal point of the historical center, is the historical urban square situated on the Mevlana road known today as Kayalı Park.The fourth and the last focal point which describes the historical city center is; the Bedesten region where the traditional Konya Bazaar is situated (Yenice,2014:72-73).

For the purpose of making Konya a cultural city, the Metropolitan Municipality of Konya has primarily started the Protection and Amelioration activities in Accordance With the Historical Vicinity and Konya Historical City Center, Protection and Development in 1996 to this end. As a result of those studies, by considering the transportation, environmental values, historical structures and their features, the zoning plan has been established and applied for protection purpose. This urban project studies has started the following planning studies in accordance with the Konya Cultural and Natural Assets Protection Council Decisions for the purpose of protecting and surviving the architectural and environmental qualifications within the historical city center. The projects which has been included within the planning and accomplished:

1.The studies of development studies related with the Railed Public Transport between Alâeddin Tepesi and Mevlana Social Complex which have been considered since 1970's, and working the Railed Public Transportation on east-west direction suggested in the Protection plan between Mevlana Social Complex and Mevlana Cultural Center and including the (Tuncer, 2006: 51) to connect the eastern part of the city are about to finish.

2. The regions of "Arasta/Bedesten", Aziziye, Kapu, İplikçi and Şerafediddin Mosque vicinity, where the traditional Konya Bazaars are intense, have been considered to become the urban conception areas (Tuncer, 2006: 54) but the historical places around the

Bedesten, Kapu Mosque and Aziziye Mosque continue to serve as the traditional urban places by getting restored.

3.The area between the Şerafeddin Mosque part, Foundations regional direction and Yap1 Kredi Bank is at the service of pedestrians today while before serving as the cab stand and parking area.

4.The landscape projects of the square between Şerafeddin Mosque part, Government Office, PTT and known as the Kayalı Park by people, are accomplished and have been applied and presented into service.

5.The ancient Konya houses around the Mevlana Social Complex vicinity have been restored and taken into service and rendered into the service of urban tourism.

The Aya Elana Church has been restored with the historical Sille houses and rendered into the faith tourism.

\section{THE CULTURAL HERITAGE OF KONYA WITHIN THE CONTEXT OF FAITH TOURISM}

The faith tourism is based on the desire of people to visit the sacred places as part of their beliefs from diverse religions. There are four reasons on accepting a place as sacred : 
1.Indication by the God of the place which is accepted as sacred(Erbaş,2002:98): The indication of the Solomon Temple to his holiness David by Yahve, (Tekvin,8:21-22) indication of Kaaba to his holiness Ibrahim (Surah of Haj, 26).

2.The participation of God at there with his allmight : Thus, it has been believed in too many religions that the God resided in the holliest part of the temple.

God's disclosure of his power there: The talk of God Yahve with his holiness Musa at the Mount Sina and according to Kur'an, his appearance there. Thus this place has been assumed as holy by the Jews.

The appearance of god there (theophany): The behaviors conducted by the Israelis on too many ancient temples they inherited from Canaanites and protected. Those temples have been considered as legalized by their God Yahve only by means of theophany for Israel (Erbaş, 2002:99).

5.Consideration of a place to be sacred by people:A place has been considered as sacred where a leader was born and grown up or got busy, the martyr graves are present or the religious saints' remembrances are preserved(Erbaş, 2002:99).

One of the first settlement centers of humanity history (7000B.C.) and having the traces of too many civilizations within the historical flow Konya, Hittite, Rome, Seljuk and Ottoman eras' artifacts, represents an open air museum identity. As it is for all the cities, Konya has a foundation story as well: According to this story, a monument has been constructed for presenting the gratitude to a person who kills a monster damaging the city, and a picture is drawn explaining that event. That monument has been named as the Iqonium. The mother goddess cult showed up in this land, has developed by converting into Cybele in Phrygia, Artemisia in Greeks and Virgin Mary in Christianity. As a result of the carried out studies, when Konya is considered in terms of Cultural and Belief Tourism, it has shown up to have important values for Christianity and Islam religions starting from the pagan culture.

In pagan cultures any city has its protective god or goddess. Facing any situation they are demanded to shelter and vows are made. The Main Goddess Zizimmene has been respected in Konya and its vicinity. In excavations carried out in Konya/Sizma that was read on a stone: 'Has made a vow to Mother Zizimmene'"(Bildirici,2006:5). On a scripture found in Konya /Meydan village, it was determined that the Light-Sky Go- Zeus' name has been written as "Dii" (Bildirici,2006:5). The universal light- Sky God has become local in diverse cultures and in Konya / Z1varık (Altınekin) it was made wov by the name "Aphia Zeus" (Bildirici,2006:10).

On another writing seen on a fountain stone in the Şeyh Ahmet Quarter, and read by the researcher Calder "Has made a vow to Meiros and his wife Damalis Zizimmene (Bildirici,2006:5).

The Paul of Tarsus who is the architect of modern day Christianity, has visited to Konya and Lystra during his visits to spread Christianity and the first seeds of this religion has drillt there. Among the important saints of Christianity, Timetheus of Lystra and Aya Thekla have converted into Christianity there.

Sille has been an important settlement situated on the Rome - Jerusalem route during the Christianity era, and the basements of Aya Elene which is the biggest church of Sille has been made during one of those sacred pilgrimage voyages in the 327 (Sarıköse,2009:8).

At the city center of Konya, on the location called Arapoğlu Makas1, there is a Roman Catholic Church dated to 1910's, which is currently open for worship.

The Anatolia, has entered into a construction era in both intellection and art by Seljukian Turks since the 11. Century and during this phase, Konya has taken its place on the world civilization history by being equipped with Turko-Islamic artistic masterworks. When told 
Konya it comes Mevlana to people's mind, when said Mevlana it comes Konya to people's mind. The tolerance idea which forms the base of the Belief Tourism, the appeal of Mevlana "Come, Whatever you be, come", the cultural activities to Remember Mevlana between the dates of 10-17 December every year continue.

Konya, today, despite all its historical phases, lives both the traditional people culture and the life circle brought by the modernity at the same time.

The Christianity and Islamic belief centers situated in the Konya city center are grouped in four:

1. Churches: The Klistra ancient settlement, Sille Aya Elana Church, Sille Cave Churches, Sille White Abbey Church, Konya Center Saint Paulus Church

2. Mosques: Alaaddin Mosque, İplikçi Mosque, Şerafettin Mosque, Sahip Ata Mosque, Konevi Mosque, Selimiye Mosque, Aziziye Mosque, Kap1 Mosque, Nakiboğlu Mosque, Şemsi Tebrizî Mosque, Hacı Fettah Mosque, Piri Mehmet Paşa Mosque, Tavusbaba Mosque.

3. Small Mosques: Meram (Hasbey) Small Mosque, Sırçalı Small Mosque, Hacı Ferruh Small Mosque, Hoca Hasan Small Mosque, Ferhuniye Small Mosque, Beyhekim Small Mosque, Zevle Sultan Small Mosque,Karatay Small Mosque.

4. Shrines: Selçuklu Sultanlar Shrine, Yeşil Shrine (Mevlana and his Family), Şemsi Tebriz-i Shrine, Sadreddin Konevi Shrine, Tavusbaba Shrine, Ateş Baz Veli Shrine, Tahir and Zühre Shrine,Ahmet Fakih Shrine, Ulaş Baba Shrine(Tapur,2009:479).

\section{CONCLUSION}

The Cultural Heritage and Urban Tourism in the Context of Belief Tourism: When the Konya Example is interrogated:

The Belief Tourism and Cultural heritage of Konya the nature, must be taken into consideration in context of cultural values and infrastructural and super-structural studies must be carried out in terms of urban tourism.

The urbanisation and urban renewal must be planned taking into consideration the touristic destinations and nature, tourist, human who form as a base for tourism.

The ways must be searched for presenting to local and foreign people, the religions and beliefs visually, audially and sensorily which are considered to be the main elements of the Belief Tourism and evaluated to be the contributive to the meeting of cultures and civilizations.

As a service sector, the educational seminaries must be held in order to form the consciousness that the tourism has environmental, sociocultural and economical dimensions.

The Cultural heritage of Konya which is currentlyalive and strong must be led up to obtain the functionality with literal projects.

The Urban Tourism is considered as the re-achievement struggle of the economical sources in the cities.

While the Urban Tourism is considered as the struggle to boost the daily life in cities in terms of socio-culture and economy, it must be designed and carried into effect in a manner not to harm the history and social tissue.

When we take a look at Konya from past to today we encounter too many artifacts. They give on one hand how the city is designed in terms of urban tourism on the other hand they should give the conception idea on how to redesign a city. 
Konya must be presented and marketed in a healthy manner by revealing more than one richnesses possible to visit.

New strategies must be determined in order to make Konya as a tourism destination the effort must be made in order to remove the obstacles to this end. Thus, the local people must be eager to tourism, the opportunity must be presented to the educated and experienced people.

\section{REFERENCES:}

1. Kur'an-1 Kerim

2. Kitab-1 Mukaddes

3. Alver Köksal, (2012), Kent Sosyolojisi Hece Yayınları, Ankara,

4. Emekli, Gözde, (2013),Öğrenen Turizm Bölgeleri Yaklaşımı ve Kent Turizmi Öğrenen Turizm Bölgeleri, Kentler ve Kent Turizmine Kuramsal Yaklaşım, 3rd International GeographySymposium - GEOMED 2013.

5. Erbaş, Ali, (2002), İslam Dışı Dinlerde Hac, Sakarya Üniversitesi İlahiyat Fakültesi Dergisi 5 / 2002,Sakarya.

6. İçellioğlu, Cansu Şarkaya,(2014) Kent Turizmi ve marka Kentler:Turizm Potansiyeli Açısından İstanbul 'un Swot Analizi, İstanbul Üniversitesi Sosyal Bilimler Dergisi, Say1: 2014 / 1, 37-55.İstanbul.

7. Kızıldere, Dicle, (2007), 1980 Sonrası İstanbul'un Tarihi Kent Merkezinde SosyoEkonomik ve Mekânsal Dönüşüm: Talimhane, Beyoğlu Örneği, Yeditepe Üniversitesi, Yüksek Lisans Tezi, İstanbul.

8. Özcan, Koray, (2009), Sürdürülebilir Kentsel Korumanın Olabilirliği Üzerine Bir Yaklaşım Önerisi: Konya Tarihi Kent Merkezi Örneği, METU JFA,2009/2

9. Sarıköse, Barış, (2009), Sille, Bin yıllık Birliktelik, Çizgi, Konya.

10. Tapur, Tahsin,(2009), Konya İlinde Kültür ve İnanç Turizmi, Uluslararası Sosyal Aratırmalar Dergisi TheJournal of International SocialResearchVolume 2 / 9 Fall

11. Tuncer, Mehmet, (2006),Tarihsel Çevre Politikaları Konya, Konya Büyükşehir Belediyesi, Konya.

12. Yenice, M.Serhat (2014),Konya Tarihi Kent Merkezi İçin Turizm Odaklı Yenileme Stratejileri,ARTIUM, Vol. 2, No.1, 2014,Gaziantep.

13. http://www.mehmetbildirici.com/post_attachment/stream?,Halkİnanışına Göre Konya'da Yatan Peygamberler

14. Erişim,2015.

15. http://www.sehirplanlama.org/index.php?option=com,Erişim,2015. 